\title{
Dynamics of Fungicide Sensitivity in Venturia effusa and Fungicide Efficacy under Field Conditions
}

\author{
J. R. Standish, T. B. Brenneman, and K. L. Stevenson, ${ }^{\dagger}$ Department of Plant Pathology, Coastal Plain Experiment Station, The University
} of Georgia, Tifton 31793

\begin{abstract}
Venturia effusa, which causes pecan scab, has developed resistance to fungicides that were once effective. Over 2 years, laboratory-based sensitivity of fentin hydroxide (TPTH) and tebuconazole in $V$. effusa and their efficacy under field conditions were compared. Leaf and nut scab were assessed on pecan trees receiving 10 applications of TPTH, tebuconazole, azoxystrobin, azoxystrobin plus tebuconazole, TPTH plus tebuconazole, or no fungicide (NTC) per year. Sensitivity of $V$. effusa on leaflets collected from treated and nontreated trees was assessed in June and September, respectively. The mean relative germination (RGe) on TPTH at $30 \mu \mathrm{g} / \mathrm{ml}$ was 10.9 and $40.9 \%$ in 2016 and 4.2 and $0.6 \%$ in 2017. Mean relative growth (RGr) on tebuconazole at $1 \mu \mathrm{g} / \mathrm{ml}$

was 45.5 and $34.6 \%$ in 2016 and 69.3 and $56.3 \%$ in 2017. In both years, leaf and nut scab were significantly lower on trees treated with azoxystrobin, azoxystrobin + tebuconazole, or TPTH + tebuconazole when compared with NTC and tebuconazole-treated trees. Compared with the NTC, tebuconazole did not significantly reduce leaf scab in 2017 or nut scab in either year, indicating that an RGr value between 34.6 and $69.3 \%$ is likely to result in a control failure on tebuconazoletreated trees. Although better activity was expected, TPTH reduced scab with RGe values between 0.6 and $40.9 \%$. These results are valuable for developing fungicide sensitivity thresholds to better predict fungicide performance.
\end{abstract}

Pecan scab, caused by Venturia effusa (G. Winter) Rossman \& W. C. Allen (syn. Fusicladium effusum), is the most economically important disease affecting pecan (Carya illinoinensis (Wangenh.) K. Koch) in the southeastern United States (Demaree 1924). This fungus causes small, olive-brown to black spots on infected leaves, fruit shucks, and twigs; young and actively growing tissues are most susceptible to infection and become resistant as they mature (Demaree 1924; Littrell and Bertrand 1981). Infections occurring on fruit during the early stages of development can cause premature fruit drop but those occurring after shell hardening are thought to be cosmetic (Bertrand 2002; Demaree 1924; Hunter 1983). The annual severity of scab is determined by cultivar susceptibility, the relative abundance of $V$. effusa inoculum, and the frequency of spring and summer rainfall (Latham 1982; Sparks et al. 2009). Rainfall events aid in the dispersal of conidia by wind and splash and the ensuing foliar moisture provides optimal conditions for conidial germination and infection (Gottwald 1982, 1985; Gottwald and Bertrand 1982; Latham 1982; Turechek and Stevenson 1998).

The most effective method of managing scab is through the use of resistant cultivars (Conner and Wells 2007). However, the scab pathogen exhibits a great amount of genetic and pathogenic diversity, which has allowed for its adaptation to cultivars with scab resistance (Bock et al. 2014, 2017b; Conner and Stevenson 2004; Demaree and Cole 1929; Sparks 1992). Thus, in the absence of durable host resistance, scab management is centered on preventive fungicide applications made throughout the growing season (Brock and Bertrand 2007a). In Georgia, the general guideline is to apply fungicides at 10- to 14-day intervals from bud break to pollination and at 14- to 21-day intervals from pollination to shell hardening, resulting in 10 or more applications per season (Brock and Bertrand 2007b).

${ }^{\dagger}$ Corresponding author: K. L. Stevenson; E-mail: ks@uga.edu

Funding: We thank the Georgia Agricultural Commodity Commission for Pecans for providing funds in support this research.

*The $\boldsymbol{e}$-Xtra logo stands for "electronic extra" and indicates that one supplementary table is published online.

Accepted for publication 26 February 2018.

C 2018 The American Phytopathological Society
However, the interval between sprays is often adjusted to once every 7 to 10 days during periods of frequent rainfall, which substantially increases the total number of applications per growing season (Brock et al. 2007; Latham 1995). Fungicides from different chemical groups are approved for use on pecan in the United States and include the methyl benzimidazole carbamates, demethylation inhibitors (DMIs), quinone outside inhibitors (QoIs), organotin compounds, phosphonates, dithiocarbamates, and guanidines (Fungicide Resistance Action Committee codes 1, 3, 11, 30, 33, M3, and U12, respectively) (Bock et al. 2017a). The inherent risk of resistance developing in $V$. effusa to the active ingredients within each of these fungicide groups ranges from low to medium to high and is magnified by the difficulty of providing uniform coverage in larger pecan trees (Bertrand and Brenneman 2001; Bock et al. 2013, 2015; FRAC 2017).

Practical fungicide resistance in $V$. effusa was first observed in the mid-1970s in association with benomyl control failures in Alabama and Georgia (Littrell 1976). Since that time, significant reductions in sensitivity have been reported in $V$. effusa isolates to the organotin fentin hydroxide (TPTH) in vitro and to the DMIs, both in vitro and as observed control failures in some locations (Reynolds et al. 1997; Seyran et al. 2010; Stevenson et al. 2004, 2015). Subsequently, a fungicide monitoring program was initiated in 2008 and further expanded in 2014 and 2015, allowing Georgia pecan producers to submit leaf samples showing typical scab symptoms for fungicide sensitivity testing (Seyran et al. 2010; Stevenson et al. 2015). Sensitivity was determined by collecting conidia directly from infected leaf material and testing either germination or microcolony growth on medium amended with dodine, TPTH, thiophanate-methyl, propiconazole, or tebuconazole, using a rapid in vitro method (Seyran et al. 2010). This assay utilized discriminatory concentrations of the aforementioned active ingredients to identify insensitivity when compared with a baseline population (Seyran et al. 2010). Studies utilizing similar in vitro laboratory assays provide an indication of relative sensitivity or insensitivity of an isolate or sample to a particular fungicide active ingredient and can be useful for detecting shifts in sensitivity over time. However, a decrease in sensitivity to a fungicide in vitro over time does not necessarily mean that practical resistance has developed or will develop if in vitro threshold levels have not yet been determined for individual fungicides. Understanding the relationship between fungicide efficacy in the orchard and sensitivity levels as measured in the laboratory is essential for development of fungicide recommendations and fungicide programs for effective scab management. The objectives of this research were to examine the 
within-season changes in sensitivity to TPTH and tebuconazole in $V$. effusa as influenced by fungicide treatment and to explore the relationship between fungicide sensitivity and efficacy in managing pecan scab under field conditions.

\section{Materials and Methods}

Field experiment and sample collection. Field experiments were conducted in a pecan orchard at the University of Georgia Ponder Farm located in Ty Ty, GA in 2016 and 2017. This orchard was originally established in 1988 with alternating rows of cultivars Desirable and Wichita planted in a square pattern with approximately $12.2 \mathrm{~m}$ between trees both within and across rows. Every other tree in all rows of both cultivars had been replanted in 2009, and these younger trees were used in this study. Each tree in the study was bordered on all sides by an older tree that was also sprayed for scab control with a program consisting primarily of Super Tin and Elast (dodine). Data were collected from Wichita, a cultivar known for being highly susceptible to scab. Fungicide treatments were applied using an air-blast sprayer in a volume of 950 liter/ha every 14 days for a total of 10 applications beginning at bud break (18 April 2016 and 8 April 2017). Although not a recommended use pattern, this strategy allowed for a direct evaluation of the efficacy of each treatment of interest. The experiment was arranged in a randomized complete block design with six treatments and five replications (blocks). The six treatments were Super Tin 4L (TPTH; United Phosphorus Inc., King of Prussia, PA), applied at a rate of 0.877 liter/ha; Orius 3.6F (tebuconazole; ADAMA Americas Inc., Aventura, FL), applied at a rate of 0.585 liter/ha; Abound (azoxystrobin; Syngenta Crop Protection, Greensboro, NC), applied at a rate of 0.877 liter/ha; Abound plus Orius $3.6 \mathrm{~F}$, applied as a tank mixture at rates of 0.877 and 0.585 liter/ha, respectively; Super Tin 4L plus Orius 3.6F, applied as a tank mixture at rates of 0.877 and 0.585 liter/ha, respectively; and a nontreated control. Treatments were applied to the same trees in both years of the study.

Disease assessments were made on a biweekly basis for 8 weeks after leaf scab symptoms were observed in each year and on a monthly basis for 2 to 3 months after nut scab symptoms were observed. Eight arbitrarily chosen terminals in the lower canopy of each tree were evaluated per tree for incidence of leaf scab and incidence and severity of nut scab. Leaf scab incidence was evaluated as the number of leaflets exhibiting symptoms of scab divided by total number of leaflets. Nut scab incidence and severity were measured as the number of nuts showing symptoms of scab divided by the total number of nuts and by estimating the percent diseased nut shuck area ranging from 0 to $100 \%$, respectively.

Fungicide sensitivity. In each year, leaflets exhibiting scab symptoms were first sampled when disease incidence was high enough to obtain an adequate sample (typically postpollination) and again just prior to shuck-split. Approximately 50 leaflets were collected from each of the 30 trees in the study on 22 June and 15 September 2016 and 15 June and 8 September 2017. Leaflets were placed in plastic bags and refrigerated $\left(4^{\circ} \mathrm{C}\right)$ until they were processed, typically within 5 days. To confirm sporulation and pathogen identity, leaf lesions were examined using a stereomicroscope to identify $V$. effusa conidia prior to testing.

Sensitivity to TPTH and tebuconazole was estimated using a slightly modified assay first described by Seyran et al. (2010). Technical-grade TPTH (98.7\% a.i.; Chem Service, Inc., West Chester, PA) and tebuconazole ( $97.5 \%$ a.i.; Bayer CropScience, Research Triangle Park, NC) were each dissolved in acetone to reach concentrations of 30,000 and $1,000 \mu \mathrm{g} / \mathrm{ml}$, respectively. A final concentration of TPTH at $30 \mu \mathrm{g} / \mathrm{ml}$ in media was obtained by adding the TPTH solution at $1 \mathrm{ml} /$ liter to autoclaved $2 \%$ water agar (WA; $20 \mathrm{~g}$ of Bacto agar per liter of water) that had cooled to $50^{\circ} \mathrm{C}$. Similarly, the final concentration of tebuconazole in media at $1 \mu \mathrm{g} / \mathrm{ml}$ was obtained by adding the tebuconazole solution at $1 \mathrm{ml} /$ liter to autoclaved quarter-strength potato dextrose agar (qPDA; $9.75 \mathrm{~g}$ of PDA and $11.25 \mathrm{~g}$ of Bacto agar per liter of water), cooled to $50^{\circ} \mathrm{C}$. A nonfungicide-amended control containing acetone at $1 \mathrm{ml} /$ liter was included for both fungicides (Seyran et al. 2010). The prepared medium was poured into disposable petri plates ( 15 by $100 \mathrm{~mm}$ in diameter) and refrigerated in the dark at $4^{\circ} \mathrm{C}$ for use within 3 days.

Each sample of leaflets per tree was divided into three groups and 15 individual lesions were selected from each group for a total of 45 lesions per sample. A 9- $\mu$ l droplet of sterile deionized water solution amended with antibiotics and Tween 20 (chloramphenicol, streptomycin sulfate, and tetracycline, each at $50 \mu \mathrm{g} / \mathrm{ml}$; and one drop Tween 20 per $100 \mathrm{ml}$, respectively) was placed onto each lesion and conidia were dislodged and collected. Conidia from each group of 15 lesions were combined in a $1.5-\mathrm{ml}$ microcentrifuge tube and suspensions were mixed well with a vortex mixer (Seyran et al. 2010).

To determine sensitivity to TPTH, $23 \mu$ l of each of the three conidial suspensions per sample were placed onto two replicate plates of TPTH-amended and nonamended WA. Conidia were incubated in the dark at $25^{\circ} \mathrm{C} \pm 2$ for $48 \mathrm{~h}$, and conidial germination was assessed for 50 arbitrarily selected conidia per replicate. A conidium was considered germinated if the length of the germ tube was at least four times the length of the conidium itself. Percent relative germination (RGe) was calculated as the proportion of germinated conidia on the fungicide-amended medium divided by the proportion of germinated conidia on nonamended medium, multiplied by 100 . This value was generated for each of the three groups, which were then averaged to yield a mean RGe value for each sample (Seyran et al. 2010).

To determine sensitivity to tebuconazole, $23 \mu$ l of each of the three conidial suspensions per sample were placed onto two replicate plates of tebuconazole-amended and nonamended qPDA. Conidia were spread using a sterile glass rod and incubated in the dark at $25^{\circ} \mathrm{C} \pm 2$ for $72 \mathrm{~h}$ (Seyran et al. 2010). After incubation, plates were examined under a compound microscope $(\times 100)$ and 10 single, wellseparated colonies were arbitrarily selected and the maximum diameter of each colony was measured. The DMI fungicides are not expected to inhibit conidial germination but are expected to inhibit hyphal growth. To correct for the average combined length of a germinated spore and the germ tube, $15 \mu \mathrm{m}$ was subtracted from all microcolony diameter measurements. Percent relative growth (RGr) was calculated as the corrected mean diameter of 10 microcolonies on the fungicide-amended medium divided by the corrected mean diameter of 10 microcolonies on the nonamended medium, multiplied by 100 . This RGr value was calculated for each of the three groups, which were then averaged to yield a mean RGr value for each sample (Seyran et al. 2010).

Data analysis. Statistical analyses were performed separately for 2016 and 2017 datasets. A mixed-model analysis was conducted using PROC GLIMMIX in SAS (version 9.4; SAS Cary, NC) to examine the effects of fungicide programs on area under the disease progress curve, maximum leaf scab incidence, maximum nut scab incidence, and maximum nut scab severity. For each of these four response variables, fungicide treatment was treated as a fixed effect, with block as a random effect. The residuals for area under the disease progress curve, maximum leaf scab incidence, maximum nut scab incidence, and maximum nut scab severity met the assumptions of normally distributed data. A repeated-measures analysis of variance was performed in PROC GLIMMIX to identify whether sampling date, fungicide treatment, or sampling date-fungicide treatment significantly affected fungicide sensitivity of $V$. effusa on TPTH or tebuconazole amended medium. Tebuconazole sensitivity (RGr) residuals met the assumptions of normally distributed data. However, the residuals of TPTH sensitivity (RGe) were nonnormal and, as such, those data were analyzed using the lognormal distribution based on $(\mathrm{RGe}+1)$ to avoid taking the logarithm of 0 .

\section{Results}

Leaf scab symptoms were first observed in late May of both 2016 and 2017; however, scab pressure and epidemic development were vastly different between the 2 years (Fig. 1). In 2016, environmental conditions were conducive for early-season scab infections, with a cumulative rainfall between 1 March and 31 May of $362 \mathrm{~mm}$ over 18 events compared with $199 \mathrm{~mm}$ over 11 events in 2017 (Supplementary Table S1). This 2016 spring rainfall resulted in greater 
amounts of leaf scab across all treatments (Table 1). Conversely, cumulative rainfall between 1 June and 31 August 2016 was $256 \mathrm{~mm}$ over 17 events compared with 379 mm over 28 events in 2017. The environment in 2017 was not conducive for early-season infection, which was reflected in the lower maximum leaf scab incidence and area under the disease progress curve values on the nontreated control trees (Table 1). The greater summer rainfall in 2017 led to first appearance of nut scab symptoms approximately 4 weeks earlier than in 2016 and maximum nut scab severity was greater on the nontreated control trees in 2017 than in 2016 (Fig. 1).

All fungicide treatments significantly reduced maximum leaf scab incidence and area under the disease progress curve when compared with the nontreated in 2016; however, Abound, Abound plus Orius 3.6F, and Super Tin 4L plus Orius 3.6F significantly reduced maximum leaf scab incidence and area under the disease progress curve when compared with the stand-alone Super Tin $4 \mathrm{~L}$ and Orius $3.6 \mathrm{~F}$ treatments (Table 1). In 2017, maximum leaf scab incidence and area under the disease progress curve were significantly lower in trees treated with Abound or Abound plus Orius 3.6F than in trees treated with all other fungicides. Trees that received the stand-alone Super Tin $4 \mathrm{~L}$ or Super Tin $4 \mathrm{~L}$ plus Orius $3.6 \mathrm{~F}$ treatments had significantly reduced maximum leaf scab incidence and trees treated with these treatments or Orius 3.6F alone had significantly reduced area under the disease progress curve when compared with the nontreated trees. There were no significant effects of treatment on maximum nut scab incidence in either year but maximum nut scab severity was significantly reduced in both years on trees treated with Abound, Abound plus Orius 3.6F, Super Tin 4L, or Super Tin 4L plus Orius 3.6F when compared with the nontreated trees (Table 1).

For RGe values on TPTH-amended medium, the fungicide treatment by date of sampling interaction was not significant $(P=0.3076)$, nor was the effect of fungicide treatment alone $(P=0.0626)$; however, RGe values did differ significantly among sampling dates $(P<0.0001)$ and, therefore, data were pooled over treatment and compared by date. For all fungicide treatments combined, insensitivity to TPTH increased significantly between 22 June and 15 September 2016, decreased significantly between 15 September 2016 and 15 June 2017, and, again, decreased significantly between 15 June and 8 September 2017 (Table 2). Similarly, for RGr values on tebuconazole-amended medium,

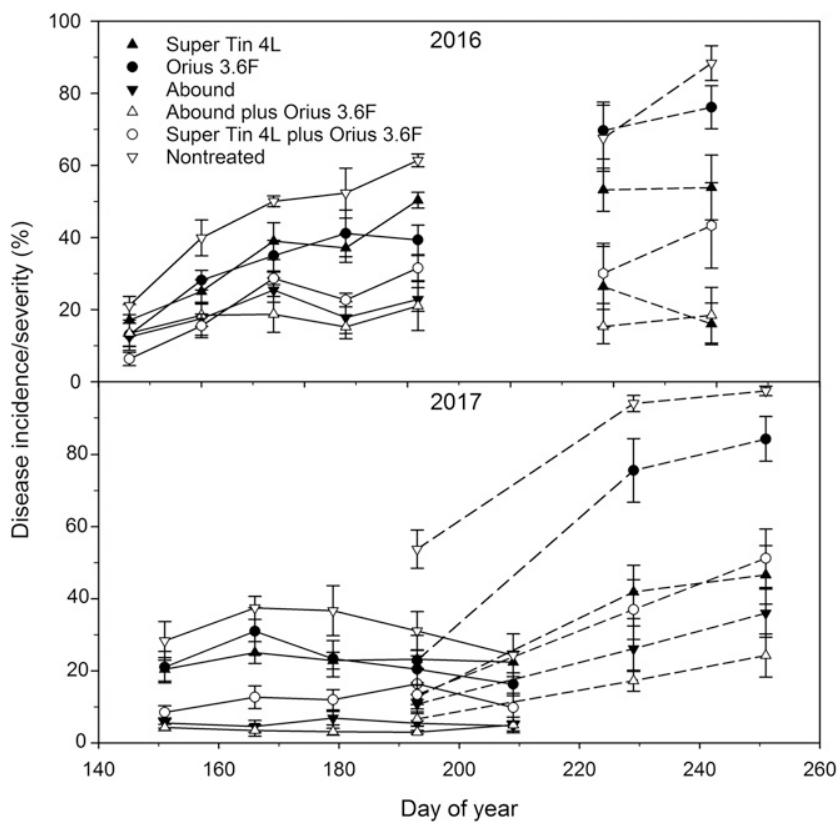

Fig. 1. Effect of biweekly fungicide applications on disease progress of pecan scab epidemics in field experiments conducted in 2016 and 2017. Leaf scab incidence (indicated by the solid line) was assessed every 2 weeks after first appearance of symptoms, from 25 May to 20 July 2016 and 31 May to 28 July 2017; nut scab severity (indicated by the dashed line) was assessed monthly during fruit development, from 25 August to 15 September 2016 and 12 July to 8 September 2017. the interaction between fungicide treatment and sampling date and fungicide treatment alone were not significant $(P=0.1079$ and 0.8906, respectively). As observed with TPTH RGe values, RGr values on tebuconazole differed significantly among sampling dates $(P<0.0001)$ and data were pooled over treatment and compared by date. Insensitivity to tebuconazole across all treatments decreased significantly between 22 June and 15 September 2016, increased significantly between 15 September 2016 and 15 June 2017, and decreased significantly from 15 June to 8 September 2017 (Table 2).

\section{Discussion}

Studies utilizing in vitro bioassays may provide an indication of relative sensitivity or insensitivity of an isolate or sample to a particular active ingredient and are useful for detecting shifts in sensitivity over time. However, a decrease in sensitivity to a fungicide in vitro does not necessarily indicate the occurrence of practical resistance. The goals of this study were to examine the within-season changes in sensitivity to TPTH and tebuconazole in $V$. effusa as influenced by fungicide treatment and to explore the relationship between fungicide sensitivity and efficacy in managing pecan scab under field conditions. As important members of the scab management arsenal, products containing these two active ingredients are heavily relied upon by pecan producers; therefore, monitoring and managing the development of resistance are very important to preserve their efficacy. The concentrations of TPTH and tebuconazole used in the sensitivity assays were initially selected based on a baseline study conducted by Seyran et al. (2010). For TPTH, the probability of an isolate sampled from the baseline population having an $\mathrm{EC}_{50}$ value greater than the discriminatory concentration of $30 \mu \mathrm{g} / \mathrm{ml}$ used herein was 0.00862 . As such, if RGe on this concentration was $0 \%$, the population on the sampled tree could be considered sensitive and an RGe greater than $0 \%$ indicated that the population was less sensitive than the historic baseline population (Seyran et al. 2010). In the same study, for the DMI fungicide propiconazole, the probability of an isolate sampled from the baseline population having an $\mathrm{EC}_{50}$ value greater than the discriminatory concentration of $1.0 \mu \mathrm{g} / \mathrm{ml}$ was $1.49 \times 10^{-7}$ (Seyran et al. 2010). Cross resistance among the DMI fungicides is common (Köller et al. 1997) and cross resistance between propiconazole and tebuconazole is known to occur in $V$. effusa; therefore, a discriminatory tebuconazole concentration of $1.0 \mu \mathrm{g} / \mathrm{ml}$ was appropriate (Stevenson et al. 2015). Thus, if $\mathrm{RGr}$ on this discriminatory concentration was $0 \%$, the population on the sampled tree was considered sensitive to tebuconazole and an RGr greater than $0 \%$ indicated that the population was less sensitive than the historic baseline population (Seyran et al. 2010). Although a quantitative relationship between RGe or RGr values and efficacy in the field was not determined in this study, some important inferences were made, as described below.

The Super Tin 4L-treated trees had consistently less leaf and nut scab than the nontreated control trees in both years of this study (Table 1). In 2016, mean RGe values on TPTH-amended medium for samples collected from trees treated with Super Tin 4L were between 10.9 and $40.9 \%$ (Table 2), and maximum leaf scab incidence, area under the disease progress curve, and maximum nut scab severity on those trees were significantly lower compared with the nontreated control trees. However, these disease measurements were significantly greater on trees treated with Super Tin $4 \mathrm{~L}$ than on those treated with Abound, Abound plus Orius 3.6F, or Super Tin 4L plus Orius 3.6F (Table 1). Mean RGe values in 2017 (4.2 and $0.6 \%$ ) were considerably lower than in 2016; maximum leaf scab incidence, area under the disease progress curve, and maximum nut scab severity on Super Tin 4L-treated trees were significantly lower than on the nontreated control trees (Tables 1 and 2). Similarly, scab intensity in 2017 was significantly lower on trees treated with Abound (maximum leaf scab incidence and area under the disease progress curve), Abound plus Orius 3.6F (maximum leaf scab incidence, area under the disease progress curve, and maximum nut scab severity), or Super Tin 4L plus Orius 3.6F (area under the disease progress curve) than on trees treated with Super Tin $4 \mathrm{~L}$ alone (Table 1). 
In 2017, the efficacy of Super Tin 4L in relation to the other treatments was greater than in 2016. This could be due to the lower spring rainfall observed in 2017 that resulted in less leaf scab early in the year and the higher summer rainfall that occurred after leaves were no longer susceptible. Super Tin $4 \mathrm{~L}$ is a protectant fungicide that is generally less effective at controlling leaf scab during the early part of the season, when rapid growth of susceptible leaf tissue occurs. Additionally, depending on the amount and timing of rainfall relative to fungicide applications, a considerable percentage of the fungicide may have been washed from the foliage during the early part of the 2016 growing season (Reynolds et al. 1994). Another possible explanation for greater relative efficacy of TPTH treatments in 2017 is the reduction in mean $R G e$ values over time that resulted in a more TPTH-sensitive population in 2017. Fungicide treatment did not significantly affect sensitivity to TPTH but sampling date did (Table 2). On the whole, insensitivity to TPTH in this orchard increased significantly between June and September 2016, decreased significantly between September 2016 and June 2017, and, again, decreased significantly between June and September 2017 (Table 2). The fact that insensitivity to TPTH decreased significantly between growing seasons in the absence of fungicide exposure, as the pathogen overwintered, may provide evidence that insensitivity to TPTH is not stable and incurs a fitness cost to this pathogen. A similar phenomenon was observed in the sugar beet pathogen Cercospora beticola, in which insensitivity to TPTH was first identified in the United States in 1994 (Bugbee 1996). Results of a 10-year fungicide sensitivity monitoring program revealed that a decrease in the frequency of TPTHinsensitive isolates occurred over time when the annual number of TPTH applications was reduced from an average of 2.14 in 1998 to $<1.0$ from 2001 to 2008 (Secor et al. 2010). Additionally, isolates of $C$. beticola insensitive to the chemically related organotin fungicides fentin acetate and fentin chloride were found to be at a competitive disadvantage when sugar beet leaves were coinoculated with sensitive isolates (Giannopolitis and Chrysayi-Tokousbalides 1980). Whether this is the case in V. effusa remains to be seen but future research is needed to further investigate the stability of TPTH insensitivity in this pathogen.

Table 1. Effects of biweekly fungicide applications on pecan scab epidemics ${ }^{\mathrm{w}}$

\begin{tabular}{|c|c|c|c|c|}
\hline \multirow[b]{2}{*}{ Year, treatment } & \multicolumn{2}{|c|}{ Leaf scab (\%) } & \multicolumn{2}{|c|}{ Nut scab (\%) } \\
\hline & $\begin{array}{l}\text { Max } \\
\text { incd }\end{array}$ & AUDPC $^{\mathbf{x}}$ & $\begin{array}{l}\text { Max } \\
\text { incd }\end{array}$ & $\begin{array}{c}\text { Max } \\
\text { sev }\end{array}$ \\
\hline \multicolumn{5}{|l|}{$2016^{y}$} \\
\hline Super Tin 4L, 0.877 liter/ha & $51.0 \mathrm{~b}$ & $18.9 \mathrm{~b}$ & $100.0 \mathrm{a}$ & $56.9 \mathrm{bc}$ \\
\hline Orius 3.6F, 0.585 liter/ha & $43.4 \mathrm{~b}$ & $18.3 \mathrm{~b}$ & $100.0 \mathrm{a}$ & $77.4 \mathrm{ab}$ \\
\hline Abound, 8.77 liters/ha & $29.8 \mathrm{c}$ & $11.0 \mathrm{c}$ & $96.5 \mathrm{a}$ & $26.0 \mathrm{~d}$ \\
\hline $\begin{array}{l}\text { Abound, } 0.877 \text { liter/ha + Orius } \\
3.6 \mathrm{~F}, 0.585 \text { liter/ha }\end{array}$ & $26.9 \mathrm{c}$ & $9.8 \mathrm{c}$ & 96.7 a & $22.2 \mathrm{~d}$ \\
\hline $\begin{array}{l}\text { Super Tin } 4 \mathrm{~L}, 0.877 \text { liter/ha }+ \\
\text { Orius } 3.6 \mathrm{~F}, 0.585 \text { liter/ha }\end{array}$ & $33.1 \mathrm{c}$ & $12.0 \mathrm{c}$ & $100.0 \mathrm{a}$ & $44.2 \mathrm{~cd}$ \\
\hline Nontreated & $61.7 \mathrm{a}$ & $25.7 \mathrm{a}$ & $100.0 \mathrm{a}$ & $86.1 \mathrm{a}$ \\
\hline \multicolumn{5}{|l|}{$2017^{z}$} \\
\hline Super Tin, 4L 0.877 liter/ha & $28.8 \mathrm{bc}$ & $13.4 \mathrm{~b}$ & $100.0 \mathrm{a}$ & $49.4 \mathrm{~b}$ \\
\hline Orius 3.6F, 0.585 liter/ha & $31.1 \mathrm{ab}$ & $13.4 \mathrm{~b}$ & $100.0 \mathrm{a}$ & $84.3 \mathrm{a}$ \\
\hline Abound, 8.77 liters/ha & $9.1 \mathrm{~d}$ & $3.2 \mathrm{~d}$ & $100.0 \mathrm{a}$ & $36.0 \mathrm{bc}$ \\
\hline $\begin{array}{l}\text { Abound, } 0.877 \text { liter/ha + Orius } \\
3.6 \mathrm{~F}, 0.585 \text { liter/ha }\end{array}$ & $7.5 \mathrm{~d}$ & $2.1 \mathrm{~d}$ & $100.0 \mathrm{a}$ & $25.5 \mathrm{c}$ \\
\hline $\begin{array}{l}\text { Super Tin } 4 \mathrm{~L}, 0.877 \text { liter/ha }+ \\
\text { Orius } 3.6 \mathrm{~F}, 0.585 \text { liter/ha }\end{array}$ & $20.2 \mathrm{c}$ & $7.3 \mathrm{c}$ & $100.0 \mathrm{a}$ & $51.2 \mathrm{~b}$ \\
\hline Nontreated & $40.9 \mathrm{a}$ & $18.9 \mathrm{a}$ & $100.0 \mathrm{a}$ & $97.5 \mathrm{a}$ \\
\hline
\end{tabular}

${ }^{\mathrm{w}}$ By year, means within columns followed by the same letter are not significantly different according to pairwise $t$ tests of least squares means $(\alpha=$ 0.05). Max incd = maximum incidence and Max sev = maximum severity.

$x$ Area under the disease progress curve (AUDPC) values calculated based on assessments of leaf scab incidence from 25 May to 20 July 2016 and 31 May to 28 July 2017.

y Applications made in 2016: 18 and 28 April, 12 and 26 May, 9 and 23 June, 7 and 21 July, and 4 and 18 August.

z Applications made in 2017: 8 and 21 April; 5 and 18 May; 1, 16, and 27 June; 13 and 27 July; and 10 August.
The efficacy of Orius 3.6F was greater relative to the other treatments in 2016 compared with 2017. In 2016, mean RGr values on tebuconazole-amended medium for samples retrieved from trees treated with Orius 3.6F were between 34.6 and $45.5 \%$ (Table 2). On those trees, significant reductions in maximum leaf scab incidence and area under the disease progress curve were observed when compared with the nontreated control trees whereas maximum nut scab severity was not significantly reduced (Table 1). Then, in 2017, mean RGr values were between 56.3 and 69.3\% (Table 2); area under the disease progress curve was significantly reduced on trees treated with Orius 3.6F but maximum leaf scab incidence and maximum nut scab severity were not significantly different from the nontreated control trees (Table 1). Applications of Orius 3.6F alone did not provide significant control of leaf or nut scab, with the exception of significantly lower maximum leaf scab incidence compared with that on the nontreated trees in 2016. This was likely due to widespread insensitivity across this orchard (Table 2). Similar to TPTH, fungicide treatment did not significantly affect tebuconazole insensitivity but sampling date did (Table 2). Across all treatments, insensitivity to tebuconazole decreased significantly within the growing season in both years and increased significantly between years (Table 2). The fact that $\mathrm{RGr}$ values decreased within season could be an artifact of the sampling protocol. In both years, the early-season sensitivity measurement was taken toward the end of the leaf expansion phase, as leaves began to reach maturity and became less susceptible to new infection. It is likely that more disease cycles occurred on fruit shucks and late-season growth flushes after that time in both years, which could have been influenced by whether new infections were coming from the same tree (autoinfection) or different ones (alloinfection) (Mundt 2009). Based on the large size of individual pecan trees, it is likely that scab within the canopy is predominantly caused by autoinfections as conidia are washed down through the canopy from the foliage above during rain events; however, the dispersal of $V$. effusa inoculum between trees is not well understood. If there are relatively greater numbers of alloinfections compared with autoinfections, then our RGr values may reflect the sensitivity of incoming conidia that had not experienced the same selection pressure. Whether this is the case or not, Orius $3.6 \mathrm{~F}$ still failed, for the most part, to significantly control scab in both years of this study, providing further evidence of practical resistance to tebuconazole in this orchard.

Previous research aimed at establishing the relationship between in vitro sensitivity and efficacy has produced mixed results. Köller et al. (1997) developed the first in vitro threshold for detection of DMI resistance when they found that isolates of $V$. inaequalis with $\mathrm{RGr}$ values greater than $80 \%$ on medium amended with fenarimol $(0.05 \mu \mathrm{g} / \mathrm{ml})$ or myclobutanil $(0.1 \mu \mathrm{g} / \mathrm{ml})$ were capable of causing practical field

Table 2. Effects of sampling date on insensitivity to fentin hydroxide and tebuconazole in Venturia effusa from fungicide-treated pecan trees

\begin{tabular}{|c|c|c|}
\hline \multirow[b]{2}{*}{ Sampling date } & \multicolumn{2}{|c|}{ Relative growth or germination $(\%)^{x}$} \\
\hline & Fentin hydroxide ${ }^{y}$ & Tebuconazole $^{\mathrm{z}}$ \\
\hline 22 June 2016 & $10.9(1.7) \mathrm{b}$ & $45.5(3.7) \mathrm{c}$ \\
\hline 15 September 2016 & $40.9(6.6) \mathrm{a}$ & $34.6(4.6) d$ \\
\hline 15 June 2017 & $4.2(0.8) \mathrm{c}$ & $69.3(3.7)$ a \\
\hline 8 September 2017 & $0.6(0.2) \mathrm{d}$ & $56.3(4.0) \mathrm{b}$ \\
\hline $\operatorname{Pr}>F$ & $<0.0001$ & $<0.0001$ \\
\hline
\end{tabular}

$\mathrm{x}$ Relative growth and germination values determined using a modified assay described by Seyran et al. (2010). Means within columns followed by the same letter are not significantly different according to pairwise $t$ tests of least squares means $(\alpha=0.05)$.

${ }^{y}$ Relative germination calculated as the proportion of germinated conidia on medium amended with fentin hydroxide at $30 \mu \mathrm{g} / \mathrm{ml}$ divided by the proportion of germinated conidia on medium without fungicide, multiplied by 100 ; values represent the means of 30 samples collected from individual treated trees per time point, with standard errors in parentheses.

${ }^{\mathrm{z}}$ Relative growth calculated as the corrected mean diameter of 10 microcolonies on medium amended with tebuconazole at $1 \mu \mathrm{g} / \mathrm{ml}$ divided by the corrected mean diameter of 10 microcolonies on medium without fungicide, multiplied by 100; values represent the means of 30 samples collected from individual treated trees per time point, with standard errors in parentheses. 
resistance. This was confirmed by conducting a greenhouse efficacy test revealing apple scab severity to be partially controlled by fenarimol or myclobutanil when leaves were inoculated with an isolate having an RGr of $88 \%$ compared with an isolate with an RGr of $42 \%$. Miller et al. (2002) found that DMI-resistant isolates of Sclerotinia homoeocarpa with mean $\mathrm{EC}_{50}$ values 5 to 10 times greater than the baseline isolates were not effectively controlled by DMI fungicides in the greenhouse. Also investigating S. homoeocarpa, Popko et al. (2012) determined that isolates from a native population exhibiting RGr values greater than $50 \%$ on medium amended with propiconazole $(0.1 \mu \mathrm{g} / \mathrm{ml})$ were capable of causing practical resistance. Conversely, Franke et al. (1998) found no significant correlation between in vitro sensitivity of Sclerotium rolfsii to tebuconazole and control of southern stem rot of peanut with tebuconazole. This lack of correlation may have occurred because the isolates used in the study were sensitive enough to be adequately controlled by the labeled rate of tebuconazole. Similarly, Thomas et al. (2012) were unable to determine the relationship between fungicide sensitivity of Stagonosporopsis citrulli (syn. Didymella bryoniae) and efficacy for gummy stem blight (GSB) management because the initial population was highly resistant at the onset of the experiment. However, it was clear that, if the frequency of resistance to boscalid, azoxystrobin, or thiophanate-methyl in the initial population was greater than 90,95 , or $80 \%$, respectively, then these fungicides were likely to be completely ineffective against GSB.

In both years of this study, Abound and Abound plus Orius 3.6F provided superior disease control when compared with all other fungicide treatments, except Super Tin $4 \mathrm{~L}$ plus Orius 3.6F (Fig. 1; Table 1). Azoxystrobin is the active ingredient in Abound and belongs to the QoI fungicide group, known to have a high risk for resistance. The fact that disease control was not compromised after 10 consecutive applications in both 2016 and 2017 provides practical evidence of a reduced risk of resistance predicted by the presence of an intron in the $V$. effusa cytochrome $b$ gene (Standish et al. 2016). These fungicides have been used on pecan since the late 1990s and practical resistance has never been reported; however, efforts to monitor QoI sensitivity have been hindered by the lack of a reliable screening method (Seyran et al. 2010; Standish et al. 2016).

An unexpected outcome of this study was that Super Tin 4L plus Orius 3.6F provided significantly greater leaf scab control in 2016 than that of either Super Tin $4 \mathrm{~L}$ or Orius $3.6 \mathrm{~F}$ alone, and significantly greater nut scab control than Orius 3.6F alone (Table 1). To a lesser extent, this trend was also observed in 2017 , with the combination resulting in significantly lower leaf scab incidence and nut scab severity than Orius 3.6F alone, and a significantly lower area under the disease progress curve than Super Tin 4L or Orius 3.6F alone (Table 1). Fungicides in the DMI group such as Orius 3.6F are known to be stronger against leaf scab due to local systemic movement. However, this increased efficacy could be explained as preserving the activity of one or both fungicides because it follows an important resistance management strategy of tank-mixing an at-risk, systemic fungicide (Orius 3.6F) with a low-risk protectant (Super Tin 4L) (Köller and Wilcox 1999).

The results of this study provide insights into the relationship between efficacy of Super Tin 4L or Orius 3.6F and laboratory-based sensitivity of $V$. effusa to TPTH or tebuconazole, respectively. The active ingredients in these two fungicides are heavily relied upon by pecan producers for scab management; therefore, monitoring and managing the development of resistance to these two chemistries is of the utmost importance. The TPTH sensitivity and efficacy results reveal that RGe values between 0.6 and $40.9 \%$ could occur without causing a likely control failure, though efficacy was reduced when compared with other treatments. However, this study shows that an RGr value between 34.6 and $69.3 \%$ is likely to result in a scab control failure for trees treated with Orius $3.6 \mathrm{~F}$ at the rate of 0.585 liter/ha. In such cases, growers are advised to keep resistance management practices in mind and utilize tank mixtures to preserve fungicide activity as a means of better managing pecan scab epidemics.

\section{Acknowledgments}

We thank C. T. Griffin, K. P. Herrington, L. L. Hickman, M. K. Lee, E. S. McBrayer, and J. C. Thompson for their technical support.

\section{Literature Cited}

Bertrand, P. F. 2002. Scab. Pages 55-57 in: Compendium of Nut Crop Diseases in Temperate Zones. B. L. Teviotdale, T. J. Michailides, and J. W. Pscheidt, eds. American Phytopathological Society, St. Paul, MN.

Bertrand, P. F., and Brenneman, T. B. 2001. Aerial and weather based fungicide application for pecan scab control. Proc. Annu. Conv. Southeast. Pecan Grow. Assoc. 94:62-69.

Bock, C. H., Brenneman, T. B., Wood, B. W., and Stevenson, K. L. 2017a. Challenges of managing disease in tall orchard trees-Pecan scab, a case study. CAB Rev. 12:1-18.

Bock, C. H., Cottrell, T. E., Hotchkiss, M. W., and Wood, B. W. 2013. Vertical distribution of scab in large pecan trees. Plant Dis. 97:626-634.

Bock, C. H., Hotchkiss, M. W., Cottrell, T. E., and Wood, B. W. 2015. The effect of sample height on spray coverage in mature pecan trees. Plant Dis. 99:916-925.

Bock, C. H., Hotchkiss, M. W., Young, C. A., Charlton, N. D., Chakradhar, M., Stevenson, K. L., and Wood, B. W. 2017b. Population genetic structure of Venturia effusa, cause of pecan scab, in the southeastern United States. Phytopathology 107:607-619.

Bock, C. H., Wood, B. W., Stevenson, K. L., and Arias, R. S. 2014. Genetic diversity and population structure of Fusicladium effusum on pecan in the United States. Plant Dis. 98:916-923.

Brock, J., and Bertrand, P. 2007a. Diseases of pecan in the southeast. Page 171 in: Southeastern Pecan Growers' Handbook. L. Wells, ed. Univ. Ga. Coop. Ext. Bull. 1327.

Brock, J., and Bertrand, P. 2007b. Pecan disease profile: Scab. Pages 185-187 in: Southeastern Pecan Growers' Handbook. L. Wells, ed. Univ. Ga. Coop. Ext. Bull. 1327.

Brock, J., Stevenson, K., and Brenneman, T. 2007. Pecan fungicides and resistance management. Pages 172-175 in: Southeastern Pecan Growers' Handbook. L. Wells, ed. Univ. Ga. Coop. Ext. Bull. 1327.

Bugbee, W. M. 1996. Cercospora beticola strains from sugar beet tolerant to triphenyltin hydroxide and resistant to thiophanate methyl. Plant Dis. 80:103.

Conner, P., and Wells, L. 2007. Pecan varieties for Georgia orchards. Pages 27-54 in: Southeastern Pecan Growers' Handbook. L. Wells, ed. Univ. Ga. Coop. Ext. Bull. 1327.

Conner, P. J., and Stevenson, K. L. 2004. Pathogenic variation of Cladosporium caryigenum isolates and corresponding differential resistance in pecan Hortscience 39:553-557.

Demaree, J. B. 1924. Pecan scab with special reference to sources of the early spring infections. J. Agric. Res. 28:321-333.

Demaree, J. B., and Cole, J. R. 1929. Behavior of Cladosporium effusum (Wint.) Demaree on some varieties of pecan. J. Agric. Res. 38:363-370.

Franke, M. D., Brenneman, T. B., and Stevenson, K. L. 1998. Stem rot of peanut: Relationship between in vitro fungicide sensitivity and field efficacy of fungicides. Peanut Sci. 25:76-80.

FRAC. 2017. FRAC Code List. Online publication. Fungicide Resistance Action Committee (FRAC), CropLife International, Brussels, Belgium. http://www. frac.info/publications/accept

Giannopolitis, C. N., and Chrysayi-Tokousbalides, M. 1980. Biology of triphenyltin-resistant strains of Cercospora beticola from sugar beet. Plant Dis. 64:940-942.

Gottwald, T. R. 1982. Spore discharge by the pecan scab pathogen, Cladosporium caryigenum. Phytopathology 72:1193-1197.

Gottwald, T. R. 1985. Influence of temperature, leaf wetness period, leaf age, and spore concentration on infection of pecan leaves by conidia of Cladosporium caryigenum. Phytopathology 75:190-194.

Gottwald, T. R., and Bertrand, P. F. 1982. Patterns of diurnal and seasonal airborne spore concentrations of Fusicladium effusum and its impact on a pecan scab epidemic. Phytopathology 72:330-335.

Hunter, R. E. 1983. Influence of scab on late season nut drop of pecans. Plant Dis. 67:806-808.

Köller, W., and Wilcox, W. F. 1999. Evaluation of tactics for managing resistance of Venturia inaequalis to sterol demethylation inhibitors. Plant Dis. 83: 857-863.

Köller, W., Wilcox, W. F., Barnard, J., Jones, A. L., and Braun, P. G. 1997. Detection and quantification of resistance of Venturia inaequalis populations to sterol demethylation inhibitors. Phytopathology 87:184-190.

Latham, A. J. 1982. Effects of some weather factors and Fusicladium effusum conidium dispersal on pecan scab occurrence. Phytopathology 72:1339-1345.

Latham, A. J. 1995. Pecan scab management in humid regions. Pages 41-44 in: Sustaining Pecan Productivity into the 21st Century, Second Natl. Pecan Workshop Proc. United States Department of Agriculture-Agricultural Research Service.

Littrell, R. H. 1976. Resistant pecan scab strains to benlate and pecan fungicide management. Pecan South 3:335-337.

Littrell, R. H., and Bertrand, P. F. 1981. Management of pecan fruit and foliar diseases with fungicides. Plant Dis. 65:769-774.

Miller, G. L., Stevenson, K. L., and Burpee, L. L. 2002. Sensitivity of Sclerotinia homoeocarpa isolates to propiconazole and impact on control of dollar spot. Plant Dis. 86:1240-1246.

Mundt, C. C. 2009. Importance of autoinfection to the epidemiology of polycyclic foliar disease. Phytopathology 99:1116-1120. 
Popko, J. T., Jr., Ok, C.-H., Campbell-Nelson, K., and Jung, G. 2012. The association between in vitro propiconazole sensitivity and field efficacy of five New England Sclerotinia homoeocarpa populations. Plant Dis. 96: $552-561$.

Reynolds, K. L., Brenneman, T. B., and Bertrand, P. F. 1997. Sensitivity of Cladosporium caryigenum to propiconazole and fenbuconazole. Plant Dis. 81:163-166.

Reynolds, K. L., Reilly, C. C., Hotchkiss, M. W., and Hendrix, F. F. 1994. Removal of fentin hydroxide from pecan seedlings by simulated rain. Plant Dis. 78:857-861

Secor, G. A., Rivera, V. V., Khan, M. F. R., and Gudmestad, N. C. 2010. Monitoring fungicide sensitivity of Cercospora beticola of sugar beet for disease management decisions. Plant Dis. 94:1272-1282.

Seyran, M., Brenneman, T. B., and Stevenson, K. L. 2010. A rapid method to monitor fungicide sensitivity in the pecan scab pathogen, Fusicladium effusum. Crop Prot. 29:1257-1263.

Sparks, D. 1992. Page 446 in: Pecan Cultivars: The Orchards Foundation. Pecan Production Innovations, Watkinsville, GA.
Sparks, D., Yates, I. E., Bertrand, P. F., and Brenneman, T. B. 2009. The relative impacts of elevation and rainy days on the incidence of scab damage of pecan nuts in the southeastern USA. J. Hortic. Sci. Biotechnol. 84:137-142.

Standish, J. R., Avenot, H. F., Brenneman, T. B., and Stevenson, K. L. 2016. Location of an intron in the cytochrome $b$ gene indicates reduced risk of QoI fungicide resistance in Fusicladium effusum. Plant Dis. 100:2294-2298.

Stevenson, K. L., Bertrand, P. F., and Brenneman, T. B. 2004. Evidence for reduced sensitivity to propiconazole in the pecan scab fungus in Georgia (Abstr.) Phytopathology 94:S99.

Stevenson, K. L., Brenneman, T. B., and Brock, J. 2015. Results of the 2014 pecan scab fungicide sensitivity monitoring program. Ga. Pecan Grow. Mag. 26: 16-23.

Thomas, A., Langston, D. B., Jr., Sanders, H. F., and Stevenson, K. L. 2012 Relationship between fungicide sensitivity and control of gummy stem blight of watermelon under field conditions. Plant Dis. 96:1780-1784.

Turechek, W. W., and Stevenson, K. L. 1998. Effects of host resistance, temperature, leaf wetness duration, and leaf age on infection and lesion development of pecan scab. Phytopathology 88:1294-1301. 